\title{
GAMBARAN PENGETAHUAN IBU HAMIL TENTANG RESIKO TINGGI KEHAMILAN DIUSIA LEBIH DARI 35 TAHUN DI LINGKUNGAN XXIX KELURAHAN BELAWAN I KECAMATAN MEDAN BELAWAN PERIODE APRIL-MEI 2018
}

\author{
Elvalini Warnelis Sinaga \\ STIKes Imelda Medan, Indonesia
}

Article Info

Keywords:

Pregnant Women

High Risk Of Pregnancy

\begin{abstract}
Pregnancy is the growth and development of an intra-uterine fetus, starting from conception and ending until the beginning of 280 days or 40 weeks calculated from the first menstruation to the last menstruation. The purpose of this study was to determine the level of knowledge of pregnant women on the risks that endanger pregnancy at the age of more than 35 years conducted by researchers from April to May 2018 in the XXIX neighborhood of Belawan I Subdistrict, Kec. Medan Belawan. This research is descriptive by using primary data, with a population of 30 respondents and pregnant women with a sample of 30 respondents using a questionnaire containing 30 questions. This study uses a total sampling technique and is located in Belawan I Village, Medan Belawan District, which is held from March to May 2018. Based on the research, there were 15 less knowledgeable respondents $(50 \%)$, reviewed based on the age of the majority aged $20-30$ years as many as 19 respondents $(63.3 \%)$, based on education the majority had high school education as many as 13 respondents $(43.3 \%)$ and based on sources information the majority got it from the public as many as 14 respondents (46.7\%). It is expected that mothers can give action to those who experience risks that endanger their pregnancies for the safety of mothers and children.
\end{abstract}

This is an open access article under the CC BY-SAlicense.

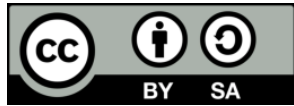

\section{Corresponding Author:}

Elvalini Warnelis Sinaga,

Program Studi D-III Kebidanan,

STIKes Imelda Medan,

Jl. Bilal No. 52 Kelurahan Pulo Brayan Darat I Kecamatan Medan Timur, Medan - Sumatera Utara.

Email: geoffreygopaz@gmail.com

\section{INTRODUCTION}

Kehamilan merupakan peristiwa yang luar biasa sehingga perhatian terhadap kesehatan ibu harus diperhatikan. Rendahnya pengetahuan ibu terhadap produksi dan pemeriksaan kesehatan selama kehamilan juga menjadi sebab tingginya kematian ibu.Mortalitas dan morbiditas pada wanita hamil adalah besar di negara berkembang. Word Health Organization (WHO) memperkirakan $35.000 \mathrm{ibu}$, pertahunnya meninggal 
saat hamil atau bersalin akibat komplikasi kehamilan yang sering terjadi sekarang ini misalnya hamil usia 20 tahun dan lebih dari 35 tahun, dan beresiko melahirkan bayi yang berkelainan genetik (Ridwanamirudin, 2007).

Survei di Amerika serikat pada tahun 2006 menunjukan, jumlah kehamilan pada wanita berusia 3539 tahun meningkat sekitar $60 \%$ di banding tahun 1990. Peningkatan yang hampir sama terjadi pada wanita dengan rentang usia 40-44 tahun, yakni sekitar 50\% usia yang paling aman padawanita untuk hamil dan melahirkan ialah sekitar 20-30 tahun, pada usia ini wanita dalam keadaan optimal dengan kata lain resiko angka kesakitan (morbiditas) dan kematian (mortalitas) ibu dan bayi yang terjadi akibat kehamilan dan persalinan dalam usia tersebut paling rendah (Gracia, 2007).

Didunia ini, terutama di Negara maju, jumlah wanita yang hamil pada usia 35 tahun atau lebih (KBI) dari tahun ketahun bertambah. Berdasarkan survey yang dilakukan di amerika serikat tahun 2006 menunjukan bahwa jumlah persalinan pada wanita berusia 35-36 tahun meningkat sekitar $60 \%$ di bandingkan tahun 1998, sedangkan pada kaum hawa yang berusia 40-44 tahun meningkat sekitar 50\% (Nurfitriana, 2005).

Pemikiran dan pernyataan itu tentu selalu menghantui kaum wanita yang ingin hamil di atas usia 35 tahun, sekarang ini banyak sekali pasangan yang memutuskan untuk menikah dan memiliki anak pada usia 35 tahun atau lebih, terutamanya di kota-kota besar jumlahnya juga cenderung meningkat dari tahun ke tahun. Karena perkembangan teknologi yang semakin meningkat, sehingga banyak wanita lebih mementingkan karir (Hanaf, 2007).

Zaman dimana banyaknya perempuan berkarir dan bekerja seperti sekarang ini, menikah di atas 30 pun sudah jamak atau banyak. Secara psikologis memang lebih matang dan financial dan juga sudah siap. Namun dari sisi fisik tidaklah demikian, mereka justru beresiko mengalami kelainan kehamilan yang membahayakan kesehatan janin. Dr. Muharam, Sp.OG dari Sam Marie Family Healty Care menuturkannya kepada human healt, beberapa resiko yang dihadapi wanita-wanita hamil di atas usia 35 tahun, yaitu janin mengalami kelainan genetik dan lahir cacat, meskipun penyakit turunan, namun menurut teori perempuan berusia separuh baya beresiko lebih besar mendapat buah hati dengan kelainan genetik (Muharam, 2007).

Di RSU. DR Pringadi Medan melaporkan kehamilan resiko tinggi sekitar 69,70\% dengan kriteria tersendiri yaitu dari kasus persalinan sebagai penyebabnya. Resiko keguguran mencapai $11,7 \%$ jika kehamilan dikisarkan umur 30-34 tahun, sedangkan diusia 35-39 tahun resiko meningkat menjadi 18\%, resiko lainnya adalah: plasenta previa, plasenta abruption, berat badan bayi kurang dari bayi baru lahir premature, paling parah adalah kemungkinan bayi menderita kelainan, seperti sindrom down (1: 952 kelahiran) dan ketidak normalan kromosom (1: 385 kelahiran). Apabila dijaga maka kehamilan di usia 40 tahun, sangat rentan terhadap keguguran. Kondisi ini di sebabkan oleh beberapa hal, seperti kualitas sel telur yang tidak lagi prima, kemungkinan dinding rahim yang mulai rapuh dan berkurang suplai darah (Grandfa, 2008).

Agar kehamilan berjalan lancar dan bayi yang di kandung juga sehat secara fisik dan mental sebaiknya sebelum hamil calon ibu yang berusia 35 tahun perlu konsultasi terlebih dahulu dengan dokter untuk memeriksakan kesehatan guna memastikan ada tidaknya kelainan genetik yang bakal terjadi pada janindan juga pada kehamilan ibu seperti penyakit hipertensi, abortus, bayi lahir cacat dan banyak lagi resiko lainnya. Dari data tersebut penulis merasa berminat untuk melakukan penelitian tentang "Gambaran pengetahuan ibu hamil tentang resiko tinggi kehamilan di usia lebih dari 35 tahun di kelurahan Belawan I lingkungan XXIX Kec Medan belawan Tahun 2018”.

\section{RESEARCH METHOD}

Jenis penelitian ini bersifat deskriptif yang bertujuan untuk mengetahui Gambaran Pengetahuan Ibu Hamil Tentang Resiko Tinggi Kehamilan diusia Lebih Dari 35 tahun Dikelurahan Belawan Tahun 2018, dengan cara melakukan penelitian dimana data langsung dikumpulkan melalui pengisian kuesioner. Populasi dalam penelitian ini adalah ibu hamil yang berusialebih dari 35 tahun Dikelurahan Belawan Kec Medan Belawan Tahun 2018 Sebanyak 30 orang. Peneliti menggunakan teknik pengumpulan total sampling (sampling jenuh) yaitu seluruh populasi yang dijadikan sampel sebanyak 30 orang. Analisa data dilakukan secara deskriptif dengan melihat presentase data yang terkumpul dan disajikan dalam bentuk tabel distribusi dan presentase. 


\section{RESULTS AND ANALYSIS}

\subsection{Hasil}

Tabel 1. Distribusi Gambaran Pengetahuan Ibu Hamil Tentang Resiko Kehamilan di Usia Lebih dari 35

Tahun di Kelurahan Belawan Kecamatan Medan Belawan Tahun 2018

\begin{tabular}{clcc}
\hline No & Pengetahuan & F & \% \\
\hline 1 & Kurang & 15 & 50 \\
\hline 2 & Cukup & 13 & 43,3 \\
\hline 3 & Baik & 2 & 6,7 \\
\hline & Jumlah & $\mathbf{3 0}$ & $\mathbf{1 0 0}$ \\
\hline
\end{tabular}

Dari tabel 1 di atas dapat dilihat bahwa mayoritas responden yang berpengetahuan kurang sebanyak 15 orang $(50 \%)$ dan minoritas responden berpengetahuan baik sebanyak 2 orang $(6,7 \%)$.

Tabel 2. Distribusi Responden Berdasarkan Pendidikan Tentang Gambaran Pengetahuan Ibu Hamil Tentang Resiko Kehamilan di Usia Lebih dari 35 Tahun di Kelurahan Belawan Kecamatan Medan Belawan Tahun 2018

\begin{tabular}{|c|c|c|c|c|c|c|c|c|c|}
\hline \multirow{3}{*}{ No } & \multirow{3}{*}{ Pendidikan } & \multicolumn{6}{|c|}{$\begin{array}{l}\text { Pengetahuan Ibu Hamil tentang Resiko Tinggi } \\
\text { Kehamilan di Usia Lebih Dari } 35 \text { Tahun }\end{array}$} & \multirow{2}{*}{\multicolumn{2}{|c|}{ Total }} \\
\hline & & \multicolumn{2}{|c|}{ Baik } & \multicolumn{2}{|c|}{ Cukup } & \multicolumn{2}{|c|}{ Kurang } & & \\
\hline & & $\mathbf{F}$ & $\%$ & $\mathbf{F}$ & $\%$ & $\mathbf{F}$ & $\%$ & $\mathbf{F}$ & $\%$ \\
\hline 1 & SD & 1 & 3,3 & 1 & 3,3 & 1 & 3,4 & 3 & 10 \\
\hline 2 & SMP & - & - & - & - & 4 & 13,3 & 4 & 13,3 \\
\hline 3 & SMA & 0 & - & 8 & 26,7 & 5 & 16,6 & 13 & 43,3 \\
\hline 4 & Perguruan Tinggi & 1 & 3,3 & 4 & 13,3 & 5 & 16,6 & 10 & 33,3 \\
\hline & Jumlah & 2 & 50 & 13 & 43,3 & 15 & 50 & 30 & 100 \\
\hline
\end{tabular}

Dari tabel 2 di atas dapat dilihat bahwa mayoritas responden yang berpendidikan SMA sebanyak 13 orang $(43,3 \%)$ dan minoritas responden berpendidikan SD sebanyak 3 orang $(10 \%)$.

Tabel 3. Distribusi Responden Berdasarkan Umur Tentang Gambaran Pengetahuan Ibu Hamil Tentang Resiko Kehamilan di Usia Lebih dari 35 Tahun di Kelurahan Belawan Kecamatan Medan Belawan Tahun

$$
2018
$$

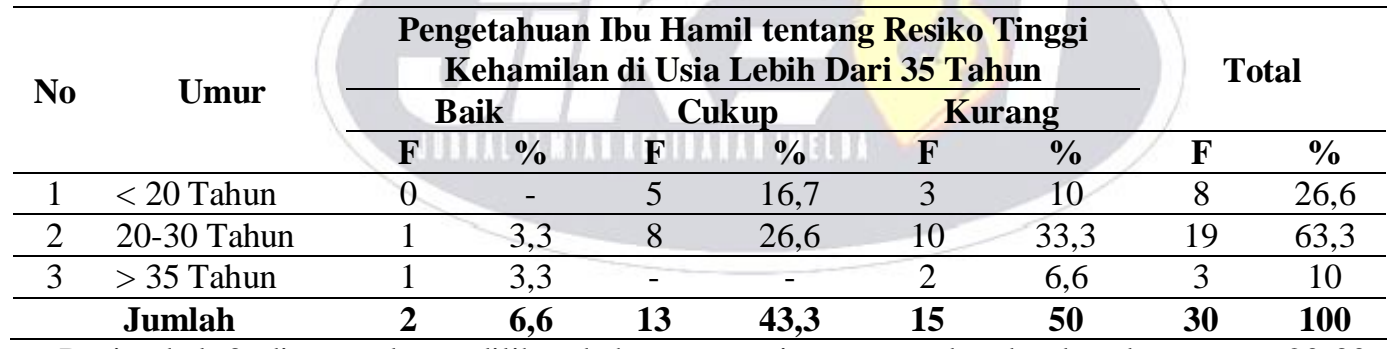

Dari tabel 3 di atas dapat dilihat bahwa mayoritas responden berdasarkan umur 20-30 tahun sebanyak 19 orang $(63,3 \%)$ dan minoritas responden berdasarkan umur $>35$ tahun sebanyak 3 orang $(10 \%)$.

Tabel 4. Distribusi Responden Berdasarkan Sumber Informasi Tentang Gambaran Pengetahuan Ibu Hamil Tentang Resiko Kehamilan di Usia Lebih dari 35 Tahun di Kelurahan Belawan Kecamatan Medan Belawan Tahun 2018

\begin{tabular}{|c|c|c|c|c|c|c|c|c|c|}
\hline \multirow{3}{*}{ No } & \multirow{3}{*}{ Sumber Informasi } & \multicolumn{6}{|c|}{$\begin{array}{c}\text { Pengetahuan Ibu Hamil tentang Resiko Tinggi } \\
\text { Kehamilan di Usia Lebih Dari 35 Tahun }\end{array}$} & \multirow{2}{*}{\multicolumn{2}{|c|}{ Total }} \\
\hline & & \multicolumn{2}{|c|}{ Baik } & \multicolumn{2}{|c|}{ Cukup } & \multicolumn{2}{|c|}{ Kurang } & & \\
\hline & & $\mathbf{F}$ & $\%$ & $\mathbf{F}$ & $\%$ & $\mathbf{F}$ & $\%$ & $\mathbf{F}$ & $\%$ \\
\hline 1 & Petugas Kesehatan & 1 & 3,3 & 4 & 13,3 & 9 & 30 & 14 & 46,6 \\
\hline 2 & Masyarakat & - & - & 8 & 26,7 & 3 & 10 & 11 & 36,7 \\
\hline 3 & Majalah Kesehatan & 1 & 3,3 & 1 & 3,3 & 3 & 10 & 5 & 16,6 \\
\hline & Jumlah & 2 & 50 & 13 & 43,3 & 15 & $\mathbf{5 0}$ & 30 & 100 \\
\hline
\end{tabular}

Dari tabel 4 di atas dapat dilihat bahwa mayoritas responden berdasarkan sumber informasi petugas kesehatan sebanyak 14 orang $(46,6 \%)$ dan minoritas responden berdasarkan sumber informasi majalah kesehatan sebanyak 5 orang $(16,6 \%)$. 


\subsection{Pembahasan}

\section{Tingkat Pengetahuan Responden Berdasarkan Tingkat Pengetahuan}

Dari tabel 1 dapat dilihat bahwa mayoritas ibu berpengetahuan kurang sebanyak 15 orang (50\%) dan minoritas responden berpengetahuan baik sebanyak 2 orang (6,7\%). Menurut (Notatmodjo, 2003) pengetahuan adalah hasil tahu dan ini terjadi setelah orang melakukan penginderaan terhadap suatu objek tertentu. Penginderaan terjadi melalui panca indera maunsia yaitu penglihatan, penciuman, pendengaran rasa dan raba. Sebagian besar pengetahuan manusia melalui mata dan telinga.

Sesuai dengan penelitian bahwa manfaat pengetahuan kurang baik, maka asumsi peneliti bahwa responden baik memperoleh informasi tentang tingkat pengetahuan ibu hamil tentang resiko kehamilan diusia lebih dari 35 tahun.

\section{Tingkat Pengetahuan Responden Berdasarkan Tingkat Pendidikan}

Berdasarkan tabel 2 dapat dilihat bahwa ibu berpengetahuan kurang dari pendidikan SD sebanyak 1 orang $(3,3 \%)$, berpengetahuan cukup sebanyak 1 orang $(3,3 \%)$, berpengetahuan baik esbanyak 1 orang $(3,3 \%)$, ibu berpengetahuan kurang dari pendidikan SMP sebanyak 4 orang $(13,3 \%)$, berpengetahuan cukup tidak ada, berpengetahuan baik tidak ada. Ibu berpengetahuan kurang dari pendidikan SMA sebanyak 5 orang $(16,7 \%)$, berpengetahuan cukup sebanyak 8 orang $(26,8 \%)$, berpengetahuan baik tidak ada. Ibu berpengetahuan kurang dari pendidikan perguruan tinggi sebanyak 5 orang $(16,7 \%)$, berpengetahuan cukup sebanyak 4 orang $(13,3 \%)$, berpengetahuan baik sebanyak 1 orang $(3,3 \%)$.

Hal ini sesuai dengan pendapat (Notoatmodjo, 2003) bahwa pendidikan adalah suatu proses yang berarti didalam pendidikan itu terjadi proses pertumbuhan, perkembangan, atua perubahan ke arah yang lebih dewasa, lebih baik dan lebih matang daripada diri individu, kelompok atau masyarakat yang mana kegiatan belajar itu menghasilkan perubahan aktual maupun potensial.

Dari uraian di atas peneliti mengasumsikan bahwa pendidikan juga dapat mempengaruhi pengetahuan seseorang. Pendidikan ini diperlukan untuk mendapatkan informasi, misalnya hal-hal yang menunjang kesehatan, sehingga dapat meningkatkan kesehatan.

\section{Tingkat Pengetahuan Responden Berdasarkan Tingkat Umur}

Berdasarkan tabel 3 dapat dilihat bahwa ibu berpengetahuan kurang dari umur $<20$ tahun sebanyak 3 orang $(10 \%)$, berpengetahuan cukup 5 orang $(16,7 \%)$, berpengetahuan baik tidak ada. Ibu berpengetahuan kurang dari umur 20-30 tahun sebanyak 8 orang (26,6\%), berpengetahuan baik sebanyak 1 orang $(3,3 \%)$. Ibu berpengetahuan kurang dari umur $>30$ tahun sebanyak 2 orang $(6,7 \%)$, berpengetahuan cukup tidak ada, berpengetahuan baik 1 orang $(3,4 \%)$.

Menurut (HULOCK, 2004) Bahwa usia seseorang akan berpengaruh terhadap apa yang dilakukan demikian halnya dengan tingkat pengetahuan ibu hamil tentang kehamilan diusia lebih dari 35 tahun, maka pada usia 20-30 tahun dikatakan sebagai usia produktif, sedangkan usia $<20$ tahun merupakan usia yang terlalu muda dan usia > 30 tahun merupakan usia tua.

Menurut asumsi peneliti bahwa pada umur 20-30 tahun merupakan usia produktif dan aman dalam mengalami kehamilan dan persalinan, sehingga tidak mudah terjadi resiko tinggi terhadap kehamilan, sedangkan ibu hamil umur $<20$ tahun dan $>30$ tahun merupakan usia yang terlalu muda dan tua, sehingga tidak produktif dan aman dalam mengalami kehamilan dan persalinan yang dapat menimbulkan resiko tinggi dalam kehamilan dan persalinan.

\section{Tingkat Pengetahuan Responden Berdasarkan Sumber Informasi}

Berdasarkan tabel 4 dapat dilihat bahwa ibu yang berpengetahuan kurang dari sumber informasi petugas kesehatan sebanyak 9 orang (30\%), berpengetahuan cukup sebanyak 4 orang (13,3\%), berpengetahuan baik sebanyak 1 orang $(3,3 \%)$. Ibu berpengetahuan kurang dari sumber informasi masyarakat sebanyak 3 orang (10\%), berpengetahuan cukup sebanyak 8 orang $(26,7 \%)$, berpengetahuan baik tidak ada, ibu berpengetahuan kurang dari sumber informasi majalah kesehatan sebanyak 3 orang (10\%), berpengetahuan cukup sebanyak 1 orang $(3,4 \%)$, berpengetahuan baik sebanyak 1 orang $(3,3 \%)$. Menurut (Notoatmodjo, 2002) bahwa sumber informasi yang diperoleh dapat mempengaruhi pengetahuan seseorang baik dari orang maupun media.

Menurut asumsi peneliti, semakin banyak seseorang mendapat informasi baik dari orang lain atau tenaga kesehatan, media massa, media cetak, semakin banyak pula sumber informasi yang diperoleh tentang kehamilan di usia lebih dari 35 tahun. 


\section{CONCLUSION}

Dari hasil penelitian terhadap tingkat pengetahuan ibu hamil tentang resiko tinggi kehamilan di usia lebih dari 35 tahun di Kelurahan Belawan Kecamatan Medan Belawan Tahun 2018 kepada 30 responden maka diambil beberapa kesimpulan sebagai berikut:

1. Dari penelitian ini diperoleh data berdasarkan pengetahuan ibu tentang resiko tinggi kehamilan di usia lebih dari 35 tahun adalah mayoritas ibu berpengetahuan kurang sebanyak 15 orang (50\%) dan minoritas ibu berpengetahuan baik sebanyak 2 orang $(6,7 \%)$.

2. Dari penelitian ini diperoleh data berdasarkan pendidikan ibu tentang resiko tinggi kehamilan di usia lebih dari 35 tahun adalah mayoritas berpendidikan SMA sebanyak 13 orang $(43,3 \%)$ dan minoritas berpendidikan SD sebanyak 3 orang (10\%).

3. Dari penelitian ini diperoleh data berdasarkan umur ibu tentang resiko tinggi kehamilan di usia lebih dari 35 tahun adalah mayoritas ibu berumur $<20$ tahun sebanyak 19 orang $(63,3 \%)$ dan minoritas ibu berumur $>35$ tahun sebanyak 3 orang $(10 \%)$.

4. Dari penelitian ini diperoleh data berdasarkan sumber informasi ibu tentang resiko tinggi kehamilan di usia lebih dari 35 tahun adalah mayoritas ibu yang mendapatkan sumber informasi dari petugas kesehatan sebanyak 8 orang $(46,7 \%)$ dan minoritas yang mendapatkan sumber informasi dari majalah kesehatan sebanyak 5 orang $(16,7 \%)$.

\section{REFERENCES}

Arikunto, S. (2002). Prosedur Penelitian Suatu Pendekatan Praktek. Edisi Revisi IV. Jakarta: Rineka Cipta. Donforta, dkk. (2002). Obstetri dan Ginekologi. Jakarta: Yayasan Bina Pustaka.

Glade, B Curtis. (2004). Kehamilan Diatas Usia 30 Tahun. Jakarta: Arca.

Grandfa. (2008). Perbedaan Kondisi Kehamilan Diusia 20, 30, 40. URL: http://www. Mother and Baby Sat/ Bambang Karsono/2008.

Manuaba. (2002). Ilmu Kebidanan Penyakit Kandungan dan Keluarga Berencana Untuk Pendidikan Bidan. Jakarta: EGC.

Murkoff, Heldi, dkk. (2008). Kehamilan Apa Yang Anda Hadapi Bulan Per Bulan. Jakarta: EGC.

Notoatmodjo, Soekidjo. (2005). Metode Penelitian Kesehatan. Jakarta: Rhineka Cipta.

Novarida, I dan Budi T.P. (2008). Tips Cerdas Kehamilan. Yogyakarta: Penerbit Oryza.

Nursalam. (2003). Konsep dan Penerapan Penelitian Masyarakat. Jakarta: Salemba Medika.

Sarwonon. (2005). Ilmu Kebidanan. Jakarta: Trisada Pilter.

Whalley, dkk. (2008). Panduan Praktis Bagi Calon Ibu Kehamilan dan Persalinan. Jakarta: Bhuana Ilmu Populer Kelompok Gramedia.

\section{BIOGRAPHIES OF AUTHORS}

\begin{tabular}{l|l|} 
Elvalini Warnelis Sinaga, Gelar D-III diperoleh dari Akademi Kebidanan Imelda \\
Medan, Jurusan Kebidanan pada tahun 2009. Gelar Sarjana diperoleh dari Poltekes \\
Kemenkes RI Medan, Jurusan Bidan Pendidik Tahun 2011. Magister Kesehatan \\
diperoleh dari Universitas Sumatera Utara, Jurusan Kesehatan Reproduksi pada tahun \\
2018. Saat ini aktif sebagai dosen tetap di Prodi D-III Kebidanan STIKes Imelda \\
Medan.
\end{tabular}

